2014. APSIM - Evolution towards a new generation of agricultural systems simulation. Environmental Modelling and Software 62: 327-350.

Jenkinson, B.A.B.; Edwards, G.R.; Bryant, R.H. 2014 Grazing behaviour, dry matter intake and urinatio patterns of dairy cows offered kale or fodder beet in winter. Proceedings of the New Zealand Society of Animal Production 74: 23-28.

Ledgard, S.F.; Finlayson, J.D.; Gavin, J.; Blackwell, M.D.; Carran, R.A.; Wedderburn, M.E.; Jollands, N.A. 2003. Resource use efficiency and environmental emissions from an average Waikato dairy farm, and impacts of intensification using nitrogen fertiliser or maize silage. Proceedings of the New Zealand Grassland Association 65: 185-189.

Nobilly, F.; Bryant, R.H.; McKenzie, B.A.; Edwards, imple and diverse pasture mixtures under irigation in Canterbury. Proceedings of the New Zealand Grassland Association 75: 165-172.

Romera, A.J.; Doole, G.J.; Beukes, P.C.; Mason, N.; Mudge, P.L. 2017. The role and value of divers sward mixtures in dairy farm systems of New
Zealand: An exploratory assessment. Agricultural Systems 152: 18-26.

Romera, A.J.; McCall, D.G.; Lee, J.M.; Agnusdei, M.G. 2009. Improving the McCall herbage growth model. New Zealand Journal of Agricultural Research 52: 477-494.

Romera, A.J.; Levy, G.; Beukes, P.C.; Clark, D.A.; Glassey, C.B. 2012. A urine patch framework to simulate nitrogen leaching on New Zealand dairy simulate nitrogen leaching on New Zealand dairy farms. Nutrient Cycling in Agroecosystems 92: 329-
346.

Sanderson, M.A.; Skinner, R.H.; Barker, D.J.; Edwards, G.R.; Tracy, B.F.; Weedon, D.A. 2004. Plant species diversity and management of temperate forage and grazing land ecosystems. Crop Science 44: 1132-1144.

Woodward, S.L.; Waghorn, G.C.; Bryant, M.A.; Benton, A. 2012. Can diverse pasture mixtures reduce nitrogen losses? Proceedings of the 5th Australasian dairy science Pymposium, Melboune, Woodward, S.L.; Waugh, C.D.; Roach, C.G.; Fynn, D.; Phillips, J. 2013. Are diverse species mixtures better pastures for dairy farming? Proceedings of the New Zealand Grassland Association 75: 79-84.

\title{
Argentine stem weevil: farmer awareness and the effectiveness of different ryegrass/endophyte associations
}

A.J. POPAY ${ }^{1}$, K. RIJSWIJK ${ }^{2}$ and S.L. GOLDSON

AgResearch Ruakura, Private Bag 3123, Hamilton 3240, New Zealand ${ }^{2}$ Wageningen University and Research, Knowledge, Technology and Innovation Group, The Netherlands ${ }^{3}$ AgResearch, Lincoln Science Centre, Private Bag 4749, Christchurch 7674, New Zealand alison.popay@agresearch.co.nz

\section{Abstract}

Argentine stem weevil (ASW) is a highly destructive pest of ryegrass that has recently been associated with increased incidences of field damage. A survey of farmer awareness and management practices in relation to this pest was carried out. Many $(47 \%)$ farmers sowed favoured plant hosts such as short-term and tetraploid ryegrasses. A field trial, undertaken near Hamilton, compared the effects on ASW larval damage of 10 different ryegrass/endophyte associations in comparison with an endophyte-free control with and without seed treatment. U2 endophyte in a diploid perennial festulolium and AR37 endophyte in a hybrid tetraploid, an Italian diploid and a tetraploid perennial ryegrass had significantly less damage $(<26 \%)$ than all other treatments $(>42 \%)$. NEA2 endophyte in a diploid perennial ryegrass and AR1 endophyte in short-term ryegrasses failed to protect plants from severe damage by this pest. Farmers need to be aware of the risks of ASW damage to short-term and tetraploid ryegrasses.

Keywords: ploidy, short-term ryegrasses, larva damage, endophyte strains, pasture management

Introduction

Argentine stem weevil (ASW) (Listronotus bonariensis) is one of New Zealand's most destructive grass and cereal pest. First reported in the country in 1927, this small cryptic insect occurs throughout New Zealand. Adult weevils feed on the emergent cotyledons of newly sown grasses and cereals, killing young seedlings (Goldson et al. 1998). The larval stages mine inside tillers, often killing the meristem and causing widespread tiller death in susceptible hosts. Between September and March ASW undergoes at least two generations in most areas except where cool temperatures (e.g. southern South Island) may slow its development allowing only one generation per year (Barker et al. 1989; Goldson et al. 1998). Damage is particularly apparent in the summer/autumn, but is often wrongly attributed to drought (Whatman 1959). An important discovery in the early 1980s showed that a seed-transmitted fungal endophyte (Epichloë festucae var. lolii; formerly Neotyphodium lolii) infecting perennial ryegrass (Lolium perenne), which ad become naturalised in New Zealand, provided its host with resistance to ASW (Prestidge et al. 1982; Mortimer \& di Menna 1983). To exploit endophytes for control of this insect, however, it was necessary to source endophyte strains that minimised or eliminate the mammalian toxicity caused by the naturalised com the nex (O) or produced them at low concentrations. In 2001, ARI, an endophyte producing the ASW deterrent, peramine, but not the toxic alkaloids was commercialised (Thon et al. 2012). This was followed in 2007 by the release of AR37 which produces epoxy-janthitrems but not peramine, ergovaline or lolitrem B. Since then seed companies have commercialised their own $E$, festucae var lolii andophyte trains such as NEA2, $E$. festrely on veramine and the toxic alkaloids an an $E$ uncinata endophyte, $\mathrm{U} 2$, isolated from meadow fescue, which produces loline alkaloids. U2 is now available in a Festulolium cv. 'Barrier' which has many of the characteristics of its meadow fescue parent.

A parasitoid (Microctonus hyperodae), that sterilise adult ASW, was imported and released in the early 1990s to provide additional control of this pest, particularly in susceptible plants not protected by endophyte. Popay et al. (2011) reported on incidenes of ASW dapye be suppressing populations. Recently, a decline in parasitism levels has been confirmed (Goldson et al 2014; Tomasetto et al. 2017). Although the reason for this decline have yet to be identified, the situation has led to concerns about farmers' current awarenes of ASW and their decision-making with regard to managing it. Seedling ryegrass and cereals that are susceptible to susceptibility to ASW is higher in Italian and annua species (Lolium multiflorum) and tetraploid perennia yegrasses compared with diploid perennials (Goldso 1982; Barker 1989; Prestidge 1991; Popay et al. 1995 that may not always be overcome by endophyteinfection (Popay et al. 2003). This paper reports on a survey seeking to gauge farmers' level of knowledge 
of ASW, as well as to understand what governs their decision making on planting, establishment methods and use of endophytes and seed treatments for grasses and cereals. With the current availability of endophytes in short-term ryegrasses and a festulolium, it was timely to also investigate ASW larval damage in a range of ryegrass/endophyte combinations in a field trial. The information from the survey and the field trial will lead to a set of recommendations on how to reduce the impact of ASW.

\section{Methods}

\section{Farmer survey}

In autumn 2015, a digital survey was planned to gai insights into the decision making process of farmers an growers in relation to insect pest management in general and ASW in particular. The survey had a sample size of 500 different farmers and growers from dairy, sheep and beef and arable sectors with an equal distributio across the main regions of New Zealand, resulting in stratified random sample of the total population. The contact details were obtained from a database owned by AssureQuality. Unfortunately, technical difficulties impacted on already tight timeframes and a digital survey was no longer deemed feasible. Instead, telephone survey was undertaken, using the same questions as would have been used in the digital survey. A sample of 2000 telephone numbers was created using AssureQuality's database, with the same requirements of an equal distribution of the sample size among the different regions of New Zealand, and only including arable, dairy, and sheep and beef farmers (e.g. farm owners, managers, sharemilkers, and others on-farm) Table 1 Percentage of tillers infected with endophyte, and percentage of tillers ( \pm SE) with any level of Argentine stem weevil larval
damage (LD) or with moderate and severe damage only for different ryegrass/endophyte combinations and a Nil control.

\begin{tabular}{lcccccc}
\hline Ryegrass types' & Ploidy & Cultivar & Endophyte & $\%$ inf. $^{4}$ & $\%$ LD $( \pm \text { SE })^{2}$ & \%LD Mod \& Sev ${ }^{2}$ \\
\hline Short & Tetra & 'Delish' & AR1 & 94 & $42.6(5.1)$ & $26.6(4.6)$ \\
Long & Tetra & 'Ohau' & AR1 & 95 & $45.3(5.1)$ & $28.4(4.6)$ \\
Long & Tetra & 'Ohau' & AR37 & 93 & $22.6(4.3)$ & $8.6(2.9)$ \\
Long & Tetra & 'Banquet II' & Endo5 & 84 & $56.0(5.4)$ & $39.3(5.3)$ \\
Italian & Tetra & 'Feast II' & Nil & 16 & $56.0(5.4)$ & $35.7(5.2)$ \\
Italian & Tetra & 'Feast II' ST ${ }^{3}$ & Nil & 13 & $42.5(5.3)$ & $27.6(4.8)$ \\
Italian & Diploid & 'Asset' & AR37 & 98 & $26.5(4.5)$ & $15.3(3.6)$ \\
Perennial & Tetra & 'Halo' & AR1 & 80 & $43.8(5.5)$ & $30.0(5.1)$ \\
Perennial & Tetra & 'Halo' & AR37 & 97 & $19.6(4.0)$ & $16.5(3.8)$ \\
Perennial & Tetra & 'Bealey' & NEA2 & 85 & $42.4(5.4)$ & $22.4(4.5)$ \\
Perennial & Diploid & 'Trojan & NEA2 & 83 & $50.6(5.5)$ & $30.1(5.0)$ \\
Perennial & Diploid & 'BarrierCombo' & U2 & 83 & $20.5(4.4)$ & $2.4(1.7)$ \\
\hline
\end{tabular}

1 Short and long rotation: Lolium boucheanum syn. L. hybridum; Italian: L. multitiforum; perennial: L. perenne.
${ }_{2}^{2}$ Percentage of tillers with larval damage based on tillers with the appropriate endophyte status.
${ }^{3}$ Seed treated with Ultrastrike.
Given the tight timeframes, it was not possible to allow the survey to run over an extended period and collect as much data as possible, instead the survey was finished as soon as there were 100 completed questionnaires. This means that the margin of error is $10 \%$, based on a $95 \%$ confidence interval (Sciencebuddies 2015). The questions covered five areas: 1. Personal information; 2. Sowing practices; 3 . Knowledge of insect pests; 4 . Awareness of ASW; 5. Sources of information. Due to the timing of the survey (i.e. before the 2015 sowing was completed), the questions regarding sowing practices focused on the year 2014. The data were

A field trial was established on a Motumaoho shallow silty peat soil in two adjoining paddocks at AgResearch's Ruakura Research Centre farm, Hamilton, Waikato (GPS coordinates: $37^{\circ} 45^{\prime} 60$ ', $\left.175^{\circ} 19^{\prime 2} 1.6^{\prime \prime E} 60\right)$ in May 2015. Existing perennial ryegrass/white clover pasture was sprayed out with thect-drilling 10 cultivar/endophyte associations, using untreated seed (Table 1). An enter seed and with seed treated with Ultrastrike to give 12 . were in one paddock and the other two in the adjacent paddock. Seed was direct-drilled at a rate of $26 \mathrm{~kg} /$ ha for tetraploid ryegrass and $20 \mathrm{~kg} / \mathrm{ha}$ for the diploid grasses. Annual tetraploid ryegrass without endophyte (cv. 'Winter Star II') was sown around the outside of the plots to ensure there was high ASW pressure within the trial. The area was rotationally grazed by cattle to control herbage mass and was not irrigated. It received a maintenance fertiliser application of superphosphate at $250 \mathrm{~kg} / \mathrm{ha}$ and selenium (Selprill) at $1 \mathrm{~kg} / \mathrm{ha}$ in late September 2015.

On $2^{\text {nd }}$ February 2016, all plots were sampled to determine the extent of ASW damage. In each plot, 25 small clumps of tillers were cut below ground level and from each clump one live tiller was selected at random for exan adult feeding scars on leaf blades was counted for each tiller, taking scar size into account, and the number of ASW eggs was recorded. Each tiller was immunoblotted for determination of its endophyte status (Simpson et al. 2014). It was then examined under magnification, if necessary, for ASW larval damage. Damage was classed as minor where there was scarring on the outside of the tiller, moderate where the larvae had penetrated and patilly mined the centre of the tiller and severe whe and severe where the tiller was extensively mined or a hole had been bored directly through the base in the region of the meristem. Dead tillers were also removed from the clumps and checked for larval damage.

Only data from live tillers with the expected endophyte status (positive for endophyte-infected, or endophyte-free in 'Nil' treatments) were analysed. Adult feeding and oviposition were analysed by ANOVA in Genstat v 16 using replicate as the blocking factor. Each of the larval damage variables was compared between treatments using a generalised linear model, assuming treatment-group-specific binomial distributions through logit link function. These analyses were carried out using Minitab version 16. The host/ endophyte combinations used in the trial did not allow analyses for effects of ploidy and ryegrass species to be undertaken.

\section{Results}

m survey

re was an over representation of sheep and beef farmers in the sample of 100 farmers that were surveyed, with $77 \%$ in this category although 22 of these farmers also had involvement in other sectors, for example, dairy support or cropping. A total of 13 respondents were dairy farmers. The majority of the respondents were over 55 and male. They predominantly had coownership of the farm, with more than 15 years farming experience, and the majority came from Canterbury $(n=18)$, Manawatu-Whanganui $(n=16)$, Otago $(n=14)$ or the Waikato $(n=13)$ regions. The results hence show a bias in the results towards South Island sheep and beef farmers; nonetheless we consider the answers relevant for a large proportion of the farmer population in New Zealand, given that the answers of the other 23 farmers were largely in line with the 77 sheep and beef farmers.

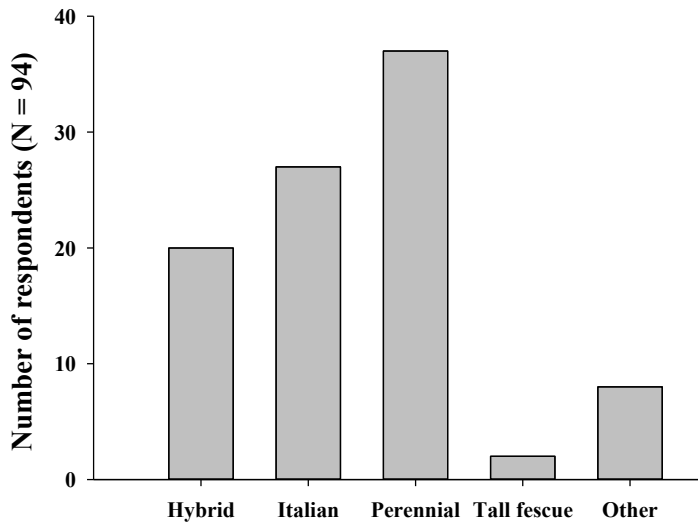

cies (Hybrid: Lolium boucheanum syn. L. hybridum; Italian: L. multitforum; perennial: L. perenne) sown by farmers in 2014, as reported 2015.

Twenty respondents had sown cereals in 2014, of which six sowed two or three different types of cereals, hence there were 28 occasions on which cereals were sown, of which $41 \%$ were barley, and $18 \%$ wheat A total of 62 respondents sowed grasses in 2014 , of whom 26 had sown more than one type of grass, resulting in 94 reports of establishment of new grasses. The majority $(\mathrm{n}=47)$ had used short-term ryegrasses (either short or long rotation/hybrids (Lolium or long rotians annuals $(\mathrm{n}=27)$, and 37 had sown perennial ryegras (Figure 1). Respondents in the category 'other' used clover, or clover and ryegrass, but did not indicate what type of ryegrass. Most $(n=30)$ reported using a diploid and the remainder $(\mathrm{n}=22)$ a tetraploid, except for Italian and annual ryegrasses where tetraploids were favoured over diploids. Interestingly, about $39 \%$ of all responses were in the 'I don't know' category.

Regarding choice of endophyte, 29 of 94 responses used AR37 while another 27 did not know which endophyte they used. Endophytes such as NEA2, Endo5, U2 and MaxPTM were not selected, although these were options where relevant. When asked what determined their choice of endophyte the majority (53\% of respondents) said previous experience was a major factor.

Of the 20 respondents who had sown cereals, $80 \%$ used insecticide-treated seed, whereas only $61 \%$ of farmers who had sown ryegrass used treated seed and $19 \%$ reported not using any seed treatment. The majority of farmers who had sown either cereals or grasses were either very satisfied $(50 \%)$ or satisfied $(40 \%)$ with establishment.

Insect pests were regarded by most respondents as being very important or important factors during establishment of pastures and cereals $(69 \%)$ as well 
as for productivity $(75 \%)$ and persistence $(73 \%)$. Hence the majority also regarded the use of seed treatment $(84 \%)$ and selection of endophyte $(68 \%)$ to be important or very important. Despite this, 50 of the 65 respondents who had sown grasses or cereal reported that they were unaware of any insect pest damage during the establishment phase. The remaining 15 thought more than one insect pest was a problem, with only two reporting ASW and/or clover root weevil as a cause of damage during establishment. Those who had sown cereals or grasses the previous year tended to be more confident in recognising insect damage.

When specifically asked about ASW, $92 \%$ of respondents had heard of this insect, but only $25 \%$ considered it to be important. This lack of concern wa not necessarily based on a well informed decision. Four respondents were not concerned about ASW because they were well informed about insect pests on their farm, for example, through a farm consultant. On the other hand, three respondents gave lack of information as a reason for not being concerned, saying "I don" really know what I'm looking for. I rely on the fac that others say, that by far the most important in thi area is grass grub and black beetle." or "I haven't been educated in recognising it." Moreover, most of those who did not consider ASW to be important on their farm attributed this to their location (e.g. southern parts of New Zealand or steep hill country). Of those 23 respondents that were concen about ASW, weevil sayng "It just devastas all the clove." Figure 2 shows that the confidence levels in recognising ASW damage varied widely; $30 \%$ said that they were somewhat confident, $27 \%$ were confident, and $24 \%$ were not confident. These results in combination with the likelihood of others confusing ASW and clover roo weevil indicate that the respondents overall were not particularly aware about ASW and its damage.

\section{Field trial}

Endophyte-infected treatments had high rates of infection $(>80 \%)$ while the Nil treatments cv. 'Feast II' contained low levels of endophyte (Table 1). All results presented on ASW damage in Table 1 pertain only to those tillers with the expected endophyte status. Adult feeding was significantly higher on the two 'Feast II' Nil treatments (Mean: 5.1 and 3.6 feeding scarstille for untreated and treated seed, respectively) than for all infected treatments $(<1.2$ scars/tiller) (SE 0.36; $\mathrm{d}$ $33, \mathrm{P}<0.001$ ). Feeding was significantly lower in 'Feast II' sown with treated seed compared with the untreated seed $(\mathrm{P}<0.05)$. There were no significant difference in the amount of adult feeding among the endophyteinfected treatments which ranged from 0.56 scars/ tiller for AR1 in 'Halo' to 1.2 scars/tiller for NEA2 in

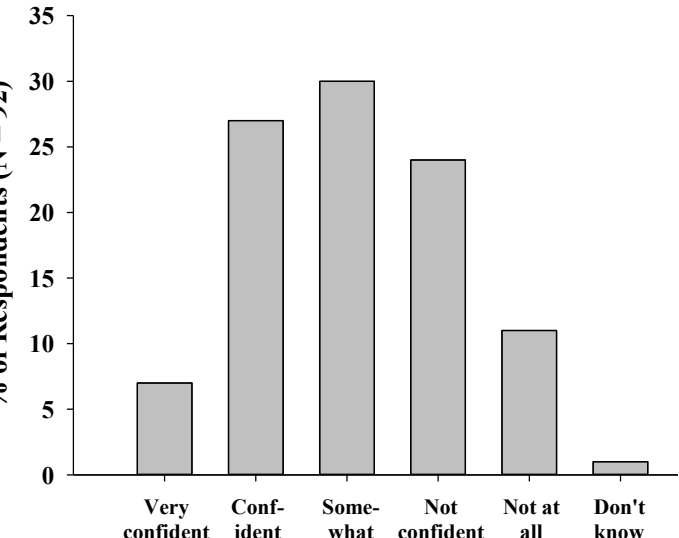

Figure 2 Farmer confidence in their ability to recognise Argentine stem weevil damage.

'Bealey'. Egg numbers on tillers sampled from each plot ranged from 0.25 in 'BarrierCombo' with U2 to 6.25 in each of the Nil and Ohau treatments, but these differences were not significant $(\mathrm{P}>0.05)$.

Over $50 \%$ of tillers in some treatments showed symptoms of larval damage including those with minor scarring on the outer leaf sheath (Table 1). U2 in a diploid perennial ('BarrierCombo') and AR37 in association with a hybrid tetraploid ('Ohau'), an Italian diploid ('Asset') and a tetraploid perennial ('Halo') had signifently less date $(P<0.01)$ the (P) all other oderate or severe damage (i.e. serious damage) in which larvae had penetrated the tiller and at least partially mined it were considered, the percentage of damaged tillers in 'BarrierCombo' U2 dropped from $20 \%$ with some level of damage to $2 \%$ with serious damage (Table 1). This treatment had fewer tillers $(\mathrm{P}<0.01)$ with this serious level of damage compared with all other treatments except the hybrid 'Ohau' with AR37. There was no difference between the three AR37 treatments. These three treatments had less moderate or severe damage than all other treatments $(\mathrm{P}<0.05)$ except for a tetraploid perennial ('Bealey') with NEA2 which was not significantly different from 'Halo' and 'Asset' infected with AR37. 'Bealey NEA2' had less damage than 'Banquet II Endo5' ( $\mathrm{P}=0.018)$, but all other treatments suffered similar levels of moderate and severe damage. -Across all treatments 404 dead tillers were checked for larval damage with the highest mean number per plot $( \pm \mathrm{SE})$ occurring in the tetraploid Italian ' $\mathrm{Nil}$ ' treatment, 'Feast II' ( $\mathrm{n}=12.8 \pm 1.6)$, and the lowest number in 'BarrierCombo U2' ( $(n=5,5 \pm 1.0)$ but this difference was not significant. The endophytes U2 in 'BarrierCombo', the three AR37 associations, AR1 in short rotation tetraploid 'Delish' and NEA2 in 'Bealey' and 'Trojan' all significantly reduced the proportion of dead tillers with larval damage compared with Nil. Overall the percentage of dead tillers that were damaged by larvae was 69 , ranging from $40 \%$ in 'BarrierCombo U2' to $85 \%$ in 'Feast Nil'. Dead tillers could not be checked for presence of endophyte.

Discussion

Several interesting points emerged from the farmer survey. Given a national average annual rate of renewal of pastures in New Zealand of 3-4\% (Pasture Renewal Charitable Trust: http://www.pasturerenewal.org.nz/), the proportion of respondents in the survey who had sown new pastures in the previous year $(62 \%)$ was high. Many of these were using the short-term grasses known to be particularly vulnerable to ASW damage. Use of seed treatment to protect young grass and cereal seedlings at establishment was common, although some chose not to, thereby running the risk of insect damage. The vast majority of farmers used endot endophyte choice based on experience, although many did not know which endophyte they had used. Most reported a high level of satisfaction with establishment of their new sowings.

Although 92 farmers had heard of ASW before, many farmers thought this insect was not posing a risk to them due mainly to their farm location. The main regions the survey respondents were located in (Waikato, Manawatu-Whanganui, Canterbury, Otago), however, are all likely to be vulnerable to ASW, with the possible exception of Otago. Cool temperatures in this and the Southland region were thought to restrict the number of generations that ASW could complete in the summer to one (Ferguson et al. 1994), but recent anecdotal evidence now suggests that two generations are more likely the norm (C.M. Ferguson pers. comm.). Many sheep and beef farmers, however, may be farming in cooler hill country areas where there is a perceived lack of risk. Nevertheless this result, and the other responses from the survey, also suggests that farmers do not recognise the insidious damage caused by this insect which often coincides with drought

The extensive use of short-term grasses and tetraploids is a concern in the light of the high levels of damage that occurred in the field trial. Moreover, these damage levels are likely to have been underestimated as they have not taken full account of the more extensive damage in the dead tillers that could not be checked for endophyte. AR1, which gives strong protection to a diploid perennial ryegrass host (Popay et al. 1999; Thom et al. 2014) did not significantly reduce the amount of moderate and severe larval damage when infecting a short rotation ryegrass, a hybrid, or a tetraploid perennial host compared to an endophytefree annual. This is likely to be due to reduced peramine concentrations in combination with the weevil's greater preference for these ryegrasses compared with diploid perennials (Popay et al. 2003). On the other hand, AR37 in similar hosts significantly reduced damage compared with both AR1 and Nil. NEA2 even in the diploid perennial, did not provide strong protection. The strongest effect on ASW, however, was exerted by the U2 endophyte which produces loline alkaloids that are known to reduce both ASW egg laying and larval damage (Jensen et al. 2009; Popay et al. 2009).

Although seed treatment is aimed at protecting seedlings during the vulnerable establishment phase, its benefits may persist in the longer term. As has occurred in other field trials (Popay \& Thom 2009), adult feeding in AR37 plots in the field trial was significantly less than Nil despite this endophyte having no effect on adult ASW (Popay \& Wyatt 1995). This almost certainly reflects a lower population of ASW in this treatment. Similarly, and unexpectedly, the seed treated Nil had significantly reduced populations of the adult weevil. Such an effect perhaps deserves more attention, even though in this case it did not result in significantly less larval damage.

Rates of parasitism of ASW in the annual tetraploid yegrass surrounding the field plots did not exceed 14\% near the end of December (P.J. Gerard pers. comm.) when a new generation of ASW was laying eggs. These parasitism levels are unlikely to have had any major impact on reducing the amount of oviposition and as a result, significant levels of damage occurred This reinforces the need for farmers to continue to be vigilant with regard to ASW. Their decisions regarding choice of ryegrass/endophyte combinations, and use of seed treatment, are critical if they want to avoid ASW larval damage. A greater level of knowledge and understanding of these issues would assist farmers in making those decisions.

\section{ACKNOWLEDGEMENTS}

This project was funded by the Sustainable Farming Fund Grant No 140701 with support from the Foundation for Arable Research, DairyNZ and Beef + Lamb New Zealand. We are grateful to AssureQuality for the use of their database, Heather Rhodes for assistance with analysis of the farmer survey, and Hamish Johnstone and Derrick Wilson for assistance with sowing. David Anderson assisted with sampling plots and Chikk van Koken conducted the statistical analysis.

\section{REFERENCES}

Barker, G.M.; Pottinger, R.P.; Addison, P.J. 1989 Population dynamics of Argentine stem weevil (Listronotus bonariensis) in pastures of Waikato, New Zealand. Agriculture, Ecosystems and Environment 26: 79-115. 
Barker, G.M. 1989. Grass host preferences of Listronotus bonariensis (Coleoptera: Curculionidae). Journal of Economic Entomology 82: 1807-1816.

Goldson, S.L. 1982. An examination of the relationship between Argentine stem weevil (Listronotu bonariensis) and several of its host grasses. New Zealand Journal of Agricultural Research 25: 395-404.

Goldson, S.L. 1981: Reproductive diapause in the Argentine stem weevil (Listronotus bonariensis (Kuschel) (Coleoptera: Curculionidae) in New Zealand. Bulletin of Entomological Research 71: 275-287.

Goldson, S.L.; Proffitt, J.R.; Baird, D.B. 1998. The bionomics of Listronotus bonariensis (Coleoptera: Curculionidae) in Canterbury, New Zealand. Bulletin of Entomological Research 88: 415-423.

Goldson, S.L.; Tomasetto, F.; Popay, A.J. 2014 Biological control against invasive species in simplified ecosystems: its triumphs and emerging simplifed ecose threats. Current Opinion in Insect Science 5: 50-56.
Jensen, J.G.; Popay, A.J.; Tapper, B.A. 2009. Argentine Jensen, J.G.; Popay, A.J.; Tapper, B.A. 2009. Argentine
stem weevil adults are affected by meadow fescue endophyte and its loline alkaloids. New Zealand Plant Protection 62: 12-18

Mortimer,P.H.; Di Menna, M.E. 1983.Lolium endophyte aetiology and the discovery of weevil resistance of ryegrass pastures infected with Lolium endophyte. Proceedings of the New Zealand Grassland Association 44: 240-243.

Popay, A.J.; Wyatt, R.T. 1995. Resistance to Argentine stem weevil in perennial ryegrass infected with endophytes producing differen alkaloids. Proceedings of the 48th New Zealand Plant Protection Conference: 229-236.

Popay, A.J.; Thom, E.R. 2009. Endophyte effects on major insect pests in Waikato dairy pasture. Proceedings of the New Zealand Grassland Association 71: 121-126.

Popay, A.J.; Hume, D.E.; Mainland, R.A.; Saunders, C.J. 1995. Field resistance to Argentine stem weevil (Listronotus bonariensis) in different ryegras cultivars infected with an endophyte deficient in lolitrem B. New Zealand Journal of Agricultural Research 38: 519-528.

Popay, A.J.; Hume, D.E.; Baltus, J.G.; Latch, G.C.M.; Tapper, B.A.; Lyons, T.B.; Cooper, B.M.; Pennell, C.G.; Eerens J.P.J.; Marshall, S.L. 1999. Field performance of perennial ryegrass (Lolium perenne) infected with toxin-free fungal endophytes (Neotyphodium spp.). Grassland Research and Practice Series 7: 113-122.
Popay,A.J.; Hume, D.E.; Davis, K.L.; Tapper, B.A. 2003. Interactions between endophyte (Neotyphodium spp.) and ploidy in hybrid and perennial ryegrass cultivars and their effects on Argentine stem weevil (Listronotus bonariensis). New Zealand Journal of Agricultural Research 46: 311-319.

Popay, A.J.; Tapper, B.A.; Podmore, C. 2009. Endophyte-infected meadow fescue and loline alkaloids affect Argentine stem weevil larvae. New Zealand Plant Protection 62: 19-27.

Popay, A.J.; McNeill, M.R.; Goldson, S.L.; Ferguson, C.M. 2011. The current status of Argentine stem weevil (Listronotus bonariensis) as a pest in the North Island of New Zealand. New Zealand Plant Protection 64: 55-62

Prestidge, R.A. 1991. Susceptibility of Italian ryegrasses (Lolium multiflorum Lam.) to Argentine stem weevil (Listronotus bonariensis (Kuschel)) feeding and oviposition. New Zealand Journal of Agricultural Research 34: 119-125.

Prestidge, R.A.; Pottinger, R.P.; Barker, G.M. 1982. An association of Lolium endophyte with ryegrass resistance to Argentine stem weevil. Proceedings of the 35th New Zealand Weed and Pest Control Conference: 119-122.

Sciencebuddies. Retrieved on 9-06-2015 from http:// www.sciencebuddies.org/science-fair-projects/ project_ideas/Soc_participants.shtml

Simpson, W.R.; Faville, M.J.; Moraga, R.A.; Williams, W.M. McManus, M.T.; Johnson, R.D. 2014 Epichloe fungal endophytes and the formation of synthetic symbioses in Hordeeae (=Triticeae) grasses. Journal of Systematics and Evolution 52: 794-806.

Thom, E.R.; Popay, A.J.; Waugh, C.D.; Minneé, E.M.K. 2014. Impact of novel endophytes in perennial ryegrass on herbage production and insect pests from pastures under diry cow grazing in nom pastures un daly cow grazing in northern New

Zealand. Grass and Forage Science 69. 191-204.

hom, E.R.; Popay, A.J.; Hume, D.E.; Fletcher, L.R. 2012. Evaluating the performance of endophytes in farm systems to improve farmer outcomes - a review. Crop and Pasture Science 63: 927-943.

Tomasetto, F.; Tylianakis, J.M.; Reale, M.; Wratten, S.; Goldson, S.L. 2017. Intensified agriculture favors evolved resistance to biological control. Proceedings of the National Academy of Sciences 114: 3885-3890. hatnan, C.P. 1959: Damnge to pastures by wheatstem weevil. New Zealand Journal of Agriculture $551-552$.

\section{Lime application can help protect pastures against black beetle}

P.J. GERARD and D.J. WILSON

AgResearch Ruakura, Private Bag 3123, Hamilton 3240, New Zealand

pip.gerard@agresearch.co.nz

\section{Abstract}

Black beetle attacks pasture grasses in the northern and coastal North beetle has more prevalent. On-farm investigations into prevention of damaging populations suggested that black beetle density was inversely related to soil $\mathrm{pH}$. Two replicated block experiments, the first in 2013-2015 on two farms, and the second on four farms in 2015-2017 investigated the effects of late spring agricultural lime applications at the rate of 5 tonne/ha on summer black beetle populations. The results showed that lime can help suppress black beetle populations. Importantly, the effect of lime persisted into the second year in Trial 2, preventing larval populations reaching damaging levels of over $40 / \mathrm{m}^{2}$. This adds to the already well-known benefits of lime in improving soil health and pasture quality, vigour and persistence.

Keywords: agricultural lime, soil $\mathrm{pH}$

\section{Introduction}

Black beetle (Heteronychus arator (Fabricius) Coleoptera: Scarabaeidae) is a subtropical pest of pasture grasses in New Zealand districts with a mean annual surface air temperature of $12.8^{\circ} \mathrm{C}$ and above (Watson 1979). This includes Northland, Waikato, Bay of Plenty and coastal areas of the northern North Island from Whanganui in the west, around to Cape Kidnappers in the east (Bell et al. 2011). With the warmest (2016) and $3^{\text {rd }}$ warmest (2013) years in the last decade and above average seasonal temperatures common (NIWA 2017), damage has become more prevalent in traditionally sporadically infested areas, and the beetle has extended its range inland and southward with sports field turf damage reported in Foxton in 2014 (B. Hannan pers. comm.).

Important factors contributing to damaging black beetle populations are above average temperatures, free-drining soils and avalibility of favoulable fod resources. Widespread black beetle outbreaks are associated with strong La Niña weather patterns which, on average, bring warmer than normal temperatures over the North Island in spring and autumn (Gerard et al. 2013). High spring temperatures (growing degree days above $15^{\circ} \mathrm{C}$, King et al. $1981 \mathrm{~b}$ ) encourage population increase while wet conditions are unfavourable for early instar larval survival (King et al. 1981c). $\mathrm{C}_{4}$ grasses, as well as ryegrasses (Lolium spp.) without we (King in turing and oviposition are reduced by ryegrasses containing standard, AR37, NEA2 or Endo 5 endophytes (Ball $e$ al. 1997; Popay \& Baltus 2001; Bell et al. 2011).

A major outbreak of black beetle occurred in Waikato and Bay of Plenty from 2007 to 2010, and many farmers experienced widespread failure of perennial pastures (Bell et al. 2011). While climate and black beetle were not the only factors, losses were reported of about . Since then, the widespread use of black beetle-active yegrass endophytes, in particular AR37, has enabled pastures to persist even under drought condition (Thom et al. 2014). However, with ongoing higher annual temperatures, pastures on peat or light soils still experience damage. Consequently there remains a high demand for additional practical tools to help combat this pest in established pastures.

In the course of analysing data gathered from 12 paddocks across five Waikato farms during a black beetle/pasture persistence study, it was found that black beetle density was inversely related to soil $\mathrm{pH}$ (Gerard $e t$ al. 2013). This paper reports on field studies undertaken to investigate if the application of agricultural lime can help reduce black beetle populations.

\section{Methods}

\section{Trial 1: 2013-2015}

The trial was a randomised block design consisting of four paddocks on Waikato dairy farms, two on a farm with peat soils (Taupiri 1 and 2, 37037'03.8”s $\left.175^{\circ} 17^{\prime} 30.9^{\prime \prime} \mathrm{E}\right)$ and two on a farm with ash soils (Waihou 1 and 2, 37 $\left.32^{\circ} 01.5^{\prime \prime} \mathrm{S} 175^{\circ} 38^{\prime} 50.0^{\prime \prime} \mathrm{E}\right)$. Each paddock (block) was divided into eight plots and AgLime supplied by McDonalds Lime (now Graymont) was applied at the rate of 5 tonne/ha to four randomly selected plots in each paddock on 4 November 2013 , by the commercial operator. Wealleans, using a purpose built $4 \times 4$ ground-spreading vehicle. The timing of the lime application was during the black beetle oviposition period.

Black beetle populations were sampled by taking five $20 \times 20 \mathrm{~cm}$ spade squares of turf to a depth of $15 \mathrm{~cm}$ and hand sorting in the field. This was done in December (a month after lime application) when the black beetle 